\title{
Inhibitory Effect of Silodosin, Tamsulosinand Terazosin in Phenylephrine Induced-Prostate Smooth Muscle Contraction (a Comparative in vitro Study)
}

\author{
Basuki B Purnomo ${ }^{1}$, Ryan Akhmad AS ${ }^{1}$, Besut Daryanto*1 and Setyawati Soeharto ${ }^{2}$ \\ ${ }^{1}$ Department of Urology, University of Brawijaya, Indonesia \\ ${ }^{2}$ Departement of Pharmacology, University of Brawijaya, Indonesia
}

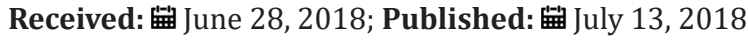

*Corresponding author: Besut Daryanto, Department of Urology, Facultyof Medicine, University of Brawijaya, Indonesia

\author{
Abstract \\ Objective: This in vitro study aims to compare the inhibitory effect of those $\alpha$-blocker to the phenylephrine inducedprostate smooth muscle \\ contraction.
}

Research Method: Twenty eight eligible BPH patients were randomly allocated to 4 groups which are one control group (without $\alpha$-blocker therapy) and 3 intervention groups treated with silodosin, tamsulosinand terazosine for 7 days prior to TURP surgery. The prostate tissue samples were taken during TURP surgery. This sample prepared on organ bath containing thyrod liquid and further induced with phenilephrin at dose 10$4 \mu \mathrm{g} / \mathrm{ml}$ to measure its contraction. A oneway anova analysis was performed to investigate the significant difference among groups.

Result: The mean contraction result in control, silodosin, tamsulosinand terazosin groups were 7,798mV, 1,718mV, 3,416mV, and 5,956 mV respectively (Table 1). There was a significant difference contraction value among 4 groups $(\mathrm{p}=0,000)$. The silodosin treatment group had the lowest mean contraction value against the controls compared with the tamsulosin and terazosin groups.

Conclusion: Silodosin has the strongest inhibitory effect in phenylephrineinduced prostate smooth muscle contraction in the invitro study. Keywords: Antagonists; Adrenoceptors; Urinary Tract; Cardiovascular system; Silodosin; Tamsulosin; Prasozin; Terazosin; Necrotic; Phenylephrine Abbreviations: LUTS: Lower Urinary Tract Symptoms; B00: Bladder Outlet Obstruction; IP3: Inositol Triphosphate; DAG: Diacylglycerol

\section{Introduction}

$\mathrm{BPH}$ is a chronic progressive disease associated with lower urinary tract symptoms (LUTS) which its prevalence increases with ageand reduces the quality of life in elderly male [1,2]. Treatment for BPH aims to relieve two types of urinary tract obstruction: mechanical urinary tract obstruction caused by tissue compression due to an enlarged prostateand functional urinary tract obstruction caused by constriction of the urinary tract and prostatic smooth muscle via sympathetic $\alpha 1$ adrenoceptors ( $\alpha 1-\mathrm{AR}$ ). As a result, $\alpha 1-\mathrm{AR}$ antagonists are widely recognized as the firstline pharmacotherapy for BPH treatment [3]. Several $\alpha 1-A R$ antagonists with its difference of selectivity are available for treatment of this disease, including silodosin, tamsulosin and terazosin. Many studies showed that those $\alpha$-blocker seem to have similar efficacy in improving symptoms and urinary flow rates [4]. The high selectivity of the $\alpha 1$-adrenergic receptor antagonist has great efficacy and is associated with minimal side effect on cardiovascular system. Based on study that was conducted on hamsters, silodosin has a very high selectivity upto 38 times compared with tamsulosin. Another study on invivo animal test subject that compared silodosin, tamsulosin, and prazosin concluded that silodosin showed the highest selectivity compared with tamsulosin and prasozin [5]

Previous invitro study has shown that long term treatment of $\alpha$ adrenergic receptor antagonists (tamsulosin $0,4 \mathrm{mg}$ once daily) in BPH patient can increase phenylephrineinduced prostate smooth muscle contraction [6]. This is probably due to a supersensitization mechanism in long term treatment. It is not yet clear, however, whether the use of adrenergic receptor antagonists in $\mathrm{BPH}$ in a short period of time can affect the contraction of smooth prostate smooth muscle.On short term crossover study comparing several types of alpha blockers, showed that 7 days treatment of alpha blocker was sufficient to determine its effectiveness and efficacy. Clinical research also suggests that different types of alpha blockers having different selectivity and affinityhave similar effectiveness on improving symptoms of IPSS and urinary outflow on BPH patient [4]. The differences in selectivity and affinity from each alpha blocker allegedly to have different effects on the prostate 
smooth muscle contractility. Therefore, research that compare the inhibitory effect of several alpha blocker against prostate smooth muscle contraction is needed.

\section{Methods}

Twentyeight eligible BPH patients having indication for surgical management were randomly allocated to 4 groups which are one control group (without $\alpha$-blocker therapy) and 3 intervention groups treated with silodosin, tamsulosinand terazosine for 7 days prior to TURP surgery. Key exclusion criteria were previous alpha blocker treatment, suspicious for prostate malignancy and patient with diabetes mellitus. The specimenwas immediately transported in cold, oxygenated tyrod's solution $\left(\mathrm{p}^{\mathrm{H}} 7,4\right)$ (composition: $135 \mathrm{NaCl}$; $5 \mathrm{KCl} ; 2,5 \mathrm{CaCl}_{2} ; 1,3 \mathrm{MgSO}_{4} ; 1,2 \mathrm{KH}_{2} \mathrm{PO}_{4} ; 20 \mathrm{NaHCO}_{3} ; 10 \mathrm{D}$-Glucose) to the laboratory. Prostate specimen were kept in aerated tyrod's buffer (95\% oxygen and $5 \%$ carbon dioxide) at a constant temperature of $37^{\circ} \mathrm{C}$ while they were cut and separated from surrounding necrotic burned tissue part and further prepared in organ bath containing aerated tyrod's buffer $\left(37^{\circ} \mathrm{C}\right)$ between stainless steel hangers. The prostate specimenwere attached to force displacement transducers and the tension was displayed on a polygraph.

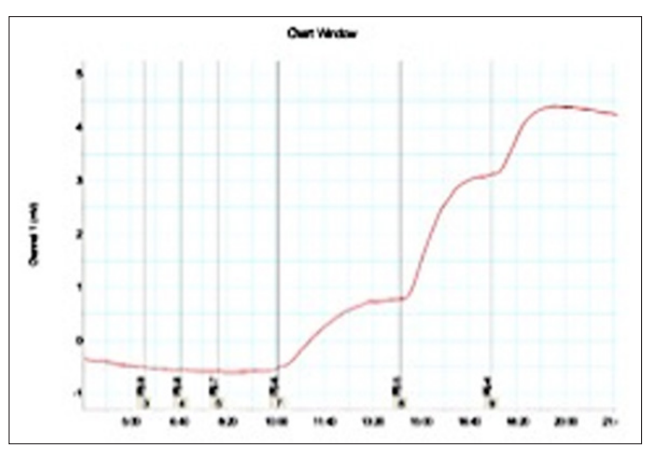

Figure 1: Graphic of prostate smooth muscle contractility in the power Lab tool with MLSO2 software from control group patients (patient Mr.B). In this graph also shows that contractionstart at exposure dose 108ug/ $\mathrm{mL}$ phenylephrine.The optimal phenylephrine is 108 .

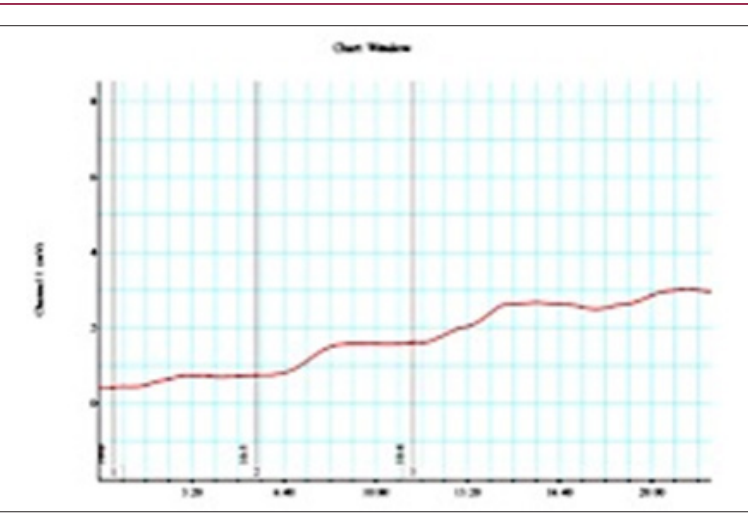

Figure 2: Graphic of prostate smooth muscle contractility on power Lab device using software from silodosin sample group. (patient Mr.T).

The signal of the pressure was digitized using the powerlabsoftware program (ADInstruments, Bella Vista, NSW, Australia). The LabChart Software Package (ADInstruments) on a computer (DELL) was used for continuous data acquisition and the subsequent analysis. The tension was set at $0,5 \mathrm{~g}$. The tissues were allowed to equilibrate in tyrod's buffer for 2 hours. After the 2-hour equilibration period, the tissue bath content was applied with $10-4 \mu \mathrm{g} / \mathrm{mL}$ phenilephrine as exogen agonist to induced tissue contractility. The contractility values of all specimens was displayed on polygraph (Figures 1-4) recorded in millivolt $(\mathrm{mV})$ and then analyzed using onewayanova test.

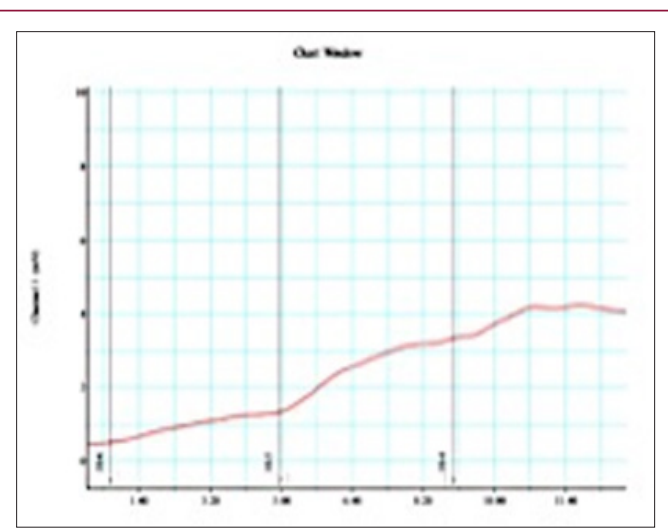

Figure 3: Graphic of prostate smooth muscle contractilityon power Lab device using chart MLSO23 software from Tamsulosin sample group.(patient Mr.AW).

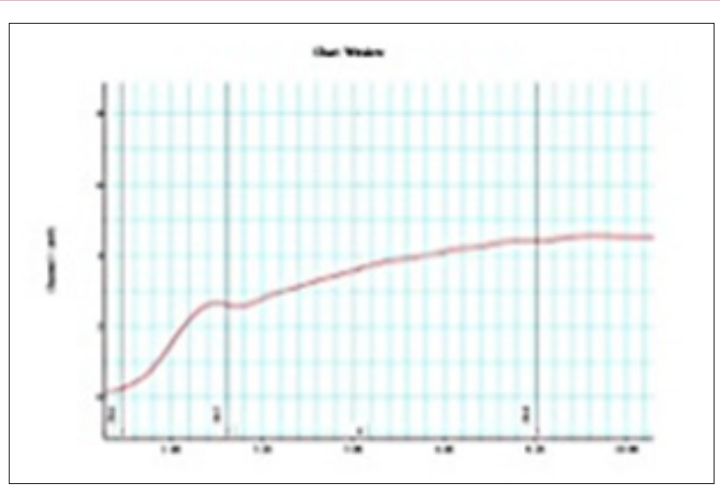

Figure 4: Graphic of prostate smooth muscle contractility on power lab device using chart MLSO23 software from Terazosin sample group. (Patient Mr.J).

\section{Results}

The result of the prostate smooth muscle contractility test using the bath organ instrument with phenylephrine exposure dose of $10-4 \mu \mathrm{g} / \mathrm{mL}$ showed significantly different $(\mathrm{p}<0.05)$ between control group compared to silodosin, tamsulosin, terazosin groups and, as shown in Table 1. Terazosin group had the highest mean contraction value compared to tamsulosin and silodosin group against control group. Silodosin group had lowest mean contraction value rate compared to tamsulosin and terazosin group against control group. The prostate contractility response in all four groups with phenylephrine dose exposure of $10-4 \mu \mathrm{g} / \mathrm{mL}$ wereanalyzed using oneway anova. The result of oneway anova analysis was presented in Table 2. One way ANOVA test results of contractility value from control, silodosin, tamsulosin, terazosin group with phenylephrine dose exposure $10-4 \mu \mathrm{g} / \mathrm{mL}$ showed sig value 0.000 $<0.05$, so it can be concluded that there is difference of prostate smooth muscle contraction value from sample that was obtained from patient control group, and groups that received silodosin, 
tamsulosin, terazosin therapy after exposed with a dose 10-4 $\mu \mathrm{g} /$ $\mathrm{mL}$ of phenilephrine. Post HocTukey Test are presented in Figure 5. The lowest contraction value was found in the group treated with silodosin and when compared between other treatment groups and control, the silodosin group had significant difference value compared with control group. There are no significant difference between tamsulosin and terazosin group compare with control group.

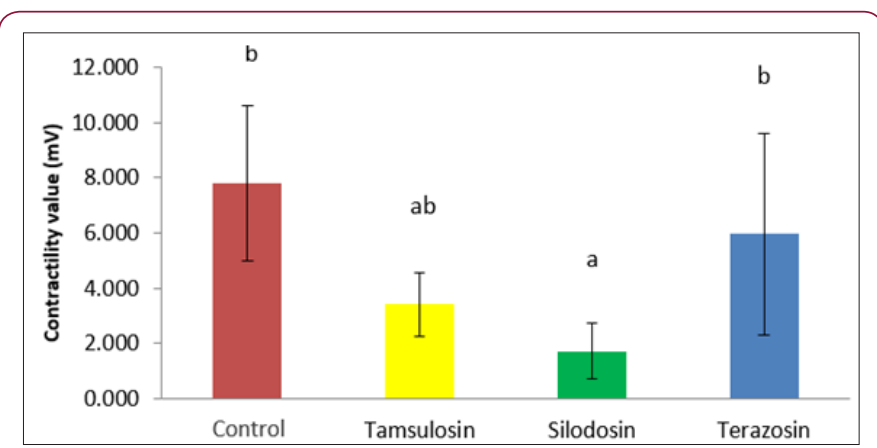

Figure 5: Post Hoc Tukey analysis of phenylephrine-induced prostate smooth muscle contraction from control, silodosin, tamsulosin and terazosin group.

Table 1: Mean values of Phenilephrine-induced prostate smooth muscle contractility.

\begin{tabular}{|c|c|c|c|}
\hline Groups & $\begin{array}{c}\text { Mean } \\
\text { Contractility } \\
\text { (mv) }\end{array}$ & Stdev & p \\
\hline Control & 7.798 & 2.789 & \multirow{2}{*}{0,000} \\
\hline Tamsulosin & 3.416 & 1.155 & \\
\hline Silodosin & 1.718 & 1.009 & \\
\hline Terazosin & 5.956 & 3.647 & \\
\hline
\end{tabular}

Table 2: One way ANOVA analysis result of phenylephrine induced prostate smooth muscle contractility among groups.

\begin{tabular}{|c|c|c|c|c|c|}
\hline Variable & $\begin{array}{c}\text { Sum of } \\
\text { square }\end{array}$ & df & $\begin{array}{c}\text { Mean } \\
\text { Square }\end{array}$ & F & Sig. \\
\hline $\begin{array}{c}\text { Between } \\
\text { groups }\end{array}$ & 11.274 & 3 & 3.758 & 9.307 & .000 \\
\hline $\begin{array}{c}\text { Within } \\
\text { groups }\end{array}$ & 9.639 & 24 & .402 & & \\
\hline Total & 20.912 & 27 & & & \\
\hline
\end{tabular}

\section{Discussion}

One of the LUTS symptoms pathophysiology in BPH patients is increased in smooth muscle tone of the prostate. Selective $\alpha 1$ adrenergic receptor antagonist is chosen as a therapy for BPH because it is effective and safe for long-term use [7-10]. These drugs act on the dynamic component of Bladder Outlet Obstruction (BO0), that reduce smooth muscle tone of the prostate and bladder neck [11]. Prostate smooth muscle contraction caused by stimulation of the adrenergic receptor by noradrenaline agonist. After ligand (adrenergic agonists) bind to the receptor, membrane phospholipids undergo hydrolysis through phospholipase C- $\beta$, resulting in a second messenger inositol triphosphate (IP3) and diacylglycerol (DAG). FurthermoreIP3 binds to IP3 receptor on endoplasmic reticulum calcium ions resulting in excretion of Calcium $\left(\mathrm{Ca}^{++}\right)$into the cytoplasm, whereas DAG together with calcium activates the enzyme protein kinase $\mathrm{C}-\alpha$ and subsequently leads to phosphorylation of several intracellular proteins. In addition, activation of this enzyme causes the opening of calcium channels in the plasma membrane that is sensitive to nifedipine (L-type $\mathrm{Ca}++$ channel) that causes more extracellular calcium slide into intracellular.

This calcium binds to calmodulin forming Ca-calmodulin which then causes contraction of the smooth muscle of the prostate [12]. In this invitro contractility studies indicate that the prostate smooth muscle contraction occurred after administration of phenilephrine as an exogenous $\alpha$-adrenergic agonist. It concludes that there is a binding process between phenilephrine as an agonist with $\alpha$-adrenergic receptor that led to the contraction of prostate smooth muscle. When the $\alpha$-adrenergic receptor antagonist binds to theadrenergic receptor, receptor activation and intracellular signaling generation were blocked. The $\alpha$-adrenergic receptor antagonists bind to the same site as the $\alpha$-adrenergic agonist that inhibits ligand binding (adrenergic agonist) with the receptor in a competitive[13,14]. In this study, when phenilephrine given on prostate smooth muscle tissue with prior $\alpha$-adrenergic antagonist therapy resulting lower value of smooth muscle contraction compared with patients without $\alpha$-adrenergic antagonist therapy. It also demonstrates that antagonists of $\alpha$-adrenergic is still bind with $\alpha$-adrenergic receptor on apart smooth muscle tissue of the prostate, so the contractility value of the prostate smooth muscle was inhibited.

In human tissue there are three subtypes of adrenergic $\alpha 1$ receptor, three of them are $\alpha 1 \mathrm{~A}, \alpha 1 \mathrm{~B}$, and $\alpha 1 \mathrm{D}$. Adrenergic $\alpha 1 \mathrm{~A}$ subtype located in the prostate tissue, bladder base, bladder neck, prostatic capsule and prostatic urethra, have a role in the contraction of the smooth muscle of the prostate [15,16]. $\alpha 1 \mathrm{~A}$ receptor subtype have $70 \%$ proportion of the population from $\alpha 1$ adrenergic receptors $[17,18]$. In prostate that undergo hyperplasia, the ratio of subtypes $\alpha 1 \mathrm{~A}, \alpha 1 \mathrm{~B}$ and $\alpha 1 \mathrm{D}$ by $85: 1: 14$ in contrast to the normal prostate, which amounted to 63: 6:31 [19]. Nowadays, there is wide range of adrenergicreceptor antagonist drugs ranging from the nonselective to selective subtype group. Silodosin has the highest selectivity when compared with tamsulosin and terazosin. Mentioned that silodosin has a higher selectivity 1400 times than terazosinand 40 times higher than with tamsulosin[5]. This study showed that administration of $\alpha$-adrenergic receptor antagonists for 7 days in BPH patients may decrease the response of prostate stromal smooth muscle contraction after exposure of exogenous $\alpha$-adrenergic receptor agonists in the invitro study. Additionally, the data showed that the mean contraction values of prostate tissue obtained from patient treated $\alpha$-adrenergic receptor antagonist silodosin, tamsulosin, terazosin for 7 days prior to surgery were significantly different $(\mathrm{p}<0.001)$.

Silodosin has the stronger inhibitory effect of prostate smooth muscle contraction compare with tamsulosin and terazosin. Mean contractility values fromsilodosin group was significantly lowercompared with control group and terazosin group. In silodosin group also has a lower mean contractility value (statistically not significant) compared with tamsulosin group. The difference of inhibitory effects in this study were related to 
differences in selectivity of these three $\alpha$-adrenergic antagonists. This research show that the highest selectivity of $\alpha$-adrenergic receptor antagonists will provide better inhibitory effect in phenylephrine-induced prostate smooth muscle contraction. The development of uroselective $\alpha$-blockers with increased affinity for the $\alpha 1 \mathrm{~A}$-adrenergic receptor over other subtypes has provided the possibility to maximize efficacy $[20,21]$. In contrast with many clinical research studies said that silodosin, tamsulosin and terazosin have the same effectiveness in improving the symptoms of IPSS and urinary emission rate of BPH patients. Tamsulosin have the same effectiveness in improving complaint LUTS compared with terazosin [22]. Other clinical research also mentioned that silodosin has the same effectiveness in improving the symptoms of LUTS compared with tamsulosin [23].

\section{Conclusion}

There is a significant difference in phenylephrine induced prostate smooth muscle contraction value among silodosin, tamsulosin and terazosin group. Silodosin has the strongest inhibitory effects in phenylephrine induced prostate smooth muscle contraction in the invitro study.This study could be one of the basic theory of the use of $\alpha$-adrenergic receptor antagonists for the treatment of $\mathrm{BPH}$.

\section{Suggestions}

More research is needed to determine the effect of $\alpha$-adrenergic receptor antagonist on the contractility of the prostate with more varied range of provision from 1 week, 2 weeks and 4 weeks in order to be the basis for consideration and the protocol for administration of antagonists adrenergic receptor- $\alpha$ in patients with BPH.More research is needed to prove that differences in selectivity and affinity of various types of receptor- $\alpha$ adrenergic antagonist related to its potential in reducing prostate contractility.

\section{References}

1. Roehrborn CG (2008) Review Pathophysiology of Benign Prostat Hyperplasia. International Journal of Impotence Research 20: 11-8.

2. Matthew R Cooperberg, Joseph C Presti, Christopher J Kane, Katsuto Shinohara, Peter R Carroll (2008) Neoplasm of the prostate Gland. Smith's General Urology (17 ${ }^{\text {th }}$ Edn.). Mc Graw Hill, USA, pp. 348-374.

3. (2003) AUA Practice Guidelines Committee. AUA guideline on management of benign prostatic hyperplasia. Chapter 1: Diagnosis and treatment recommendations. J Urol 170: 530-547.

4. Araki T, Monden K, Araki M (2013) Comparison of 7 alpha (1) adrenoceptor antagonists in patients with lower urinary tract symptoms associated with benign prostatic hyperplasia:a short-term crossover study. Acta Med Okayama 67(4): 245-251.

5. Cantrell MA, Bream Rouwenhorst HR, Hemerson P, Magera JS Jr (2010) Silodosin for Benign Prostatic Hyperplasia. Ann Pharmacother 44(2): 302-310.

6. Arliyansyah FK, Purnomo BB Soeharto S (2014) The Effect of Long Term Treatment $\alpha$-adrenergic Receptor Antagonists in men with BPH on Prostate Muscle Tone response after exposed by $\alpha$-adrenergic Receptor Agonists Thesis. University of Brawijaya MalangIndonesia.
7. Dutkiewicz S (2004) Long-Term Treatment With Doxazosin In Men With Benign Prostatic Hyperplasia: 10-Year Follow-Up. International Urology and Nephrology 36(2): 169-173.

8. Narayan P, Tunuguntla HSGR (2005) Long-Term Efficacy and Safety of Tamsulosin for Benign Prostatic Hyperplasia. Rev Urol7(4): 42-48.

9. Haillot O, Fraga A, Maciukiewicz P, Pushkar D, Tammela T, et al. (2011) The Effects Of Combination Therapy with Dutasteride plus Tamsulosin on clinical outcomes in men with Symptomatic BPH: 4-Year Post Hoc Analysis of European men in the Combat Study. Prostate Cancer and Prostatic Diseases 14(4): 302-306.

10. Gravas S, Bachmann A, Descazeaud A, Drake M, Gratzke C, et al. (2014) Guidelines on The Management of Non-Neurogenic Male LUTS, BPO. EAU Guidelines p. 30.

11. Novara G, Galfano A, Berto RB, Ficarra V, Navarrete RV, et al. (2006) Inflammation, Apoptosis, and BPH: What is the Evidence? European Urology Supplements 5(4): 401-409.

12. Albert B, Johnson A, Lewis J, Raff M, Robert K, et al. (2002) Cell Communication. Dalam: Molecular Biology of The Cell, Edisi ke 4, Gardland Publishing, Inc, New York, USA, pp. 831-906.

13. Foreman JC, Johansen T (2003) Textbook of Receptor Pharmacology Second Edition. CRC Press LLC, 1(4): 30-31.

14. Katzung BG, Masters SB, Trevor AJ (2011) Basic and Clinical Pharmacology (12 ${ }^{\text {th }}$ Edition). San Fransisco 1: 6-7.

15. Michel MC(2010) The Pharmacological Profile of The $A_{1 a}$-Adrenoceptor Antagonist Silodosin. EurUrol 4(9): 486-490.

16. Roehrborn CG, Schwinn DA (2004) A1-Adrenergic Receptors and Their Inhibitors In Lower Urinary Tract Symptoms And Benign Prostatic Hyperplasia. J Urol 171: 1029-1035.

17. Faure C, Pimoule C, Vallancien G (1994) Identification of A1Adrenoceptor Subtypes Present in the Human Prostate Life Science. 54: 1595-1605.

18. Lepor H (2007) Alpha Blockers for the Treatment of Benign Prostatic Hyperplasia. Rev Urol 9(4): 181-190.

19. Nasu K, Moriyama N, Kawabe K, Tsujimoto G, Murai M, et al. (1996) Quantification and Distribution of Alpha 1-Adrenoceptor Subtype Mrnas in Human Prostate: Comparison of Benign Hypertrophied Tissue And Non-Hypertrophied Tissue. Br J Pharmacol. 119(5):797-803.

20. Beduschi, Mario C, Beduschi R, Oesterling JE, et al. (1998) AlphaBlockade Therapy for Benign Prostatic Hyperplasia: from a Nonselective to a More Selective Alpha ${ }_{1 \mathrm{~A}}$-Adrenergic Antagonist. Urology51(6): 861872 .

21. Osman NI, Capple CR Tammela TL, Eisenhardt A, Oelke M (2015) Open Label, 9 Month ExtensionStudy Investigating The Uro-Selective Alpha Blocker Silodosin In Men With LUTS Associated With BPH. World J Urol 33: 697-706.

22. Lee C, Lee E (1997) Clinical Comparison of Selective And Non-Selective Alpha-Adrenoreceptor Antagonists In Benign Prostatic Hyperplasia: Studies on Tamsulosin In A Fixed Dose And Terazosin In Increasing Doses. British Journal of Urology 80(4): 606-661.

23. Yokohama T, Hara R, Fujii T, Jo Y, Miyaji Y, et al. (2012) Comparison of Two Different $\alpha 1$-Adrenoceptor Antagonists, Tamsulosin and Silodosin, in the Treatment of Male Lower Urinary Tract Symptoms Suggestive of Benign Prostatic Hyperplasia: A Prospective Randomized Crossover Study. LUTS. 4(1): 14-18. 


\section{ISSN: 2574-1241}

DOI: 10.26717/BJSTR.2018.06.001401

Besut Daryanto. Biomed J Sci \& Tech Res

(c) (i) This work is licensed under Creative

Submission Link: https://biomedres.us/submit-manuscript.php

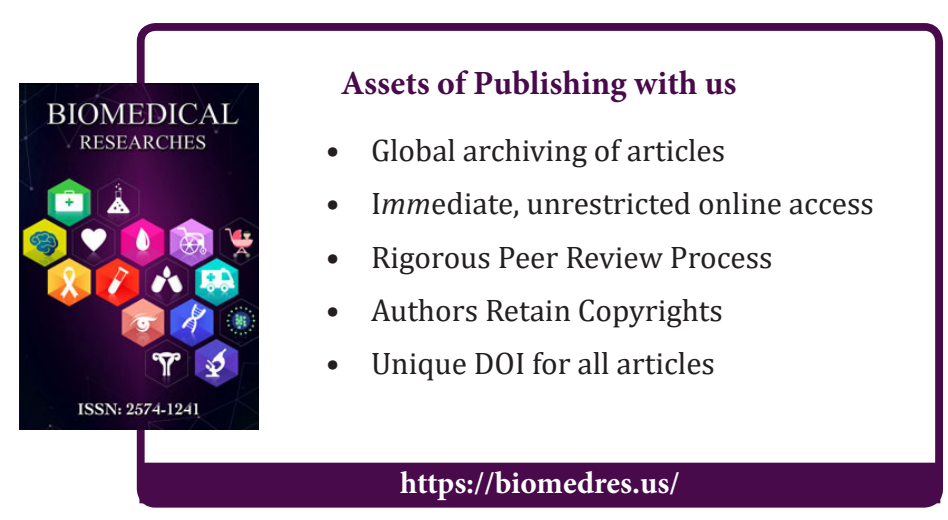

